\title{
Antitumor Activity of Chinese Propolis in Human Breast Cancer MCF-7 and MDA-MB-231 Cells
}

\author{
Hongzhuan Xuan, ${ }^{1}$ Zhen Li, ${ }^{1}$ Haiyue Yan, ${ }^{2}$ Qing Sang, ${ }^{1}$ Kai Wang, ${ }^{3}$ Qingtao He, \\ Yuanjun Wang, ${ }^{1}$ and Fuliang $\mathrm{Hu}^{3}$ \\ ${ }^{1}$ School of Life Science, Liaocheng University, Liaocheng 252059, China \\ ${ }^{2}$ School of Life Science, Anhui University, Hefei 230039, China \\ ${ }^{3}$ College of Animal Sciences, Zhejiang University, Hangzhou 310029, China
}

Correspondence should be addressed to Fuliang Hu; flhu@zju.edu.cn

Received 10 February 2014; Revised 10 April 2014; Accepted 13 April 2014; Published 22 May 2014

Academic Editor: Thomas Efferth

Copyright (C) 2014 Hongzhuan Xuan et al. This is an open access article distributed under the Creative Commons Attribution License, which permits unrestricted use, distribution, and reproduction in any medium, provided the original work is properly cited.

\begin{abstract}
Chinese propolis has been reported to possess various biological activities such as antitumor. In present study, anticancer activity of ethanol extract of Chinese propolis (EECP) at 25, 50,100, and $200 \mu \mathrm{g} / \mathrm{mL}$ was explored by testing the cytotoxicity in MCF-7 (human breast cancer ER(+)) and MDA-MB-231 (human breast cancer ER(-)) cells. EECP revealed a dose- and time-dependent cytotoxic effect. Furthermore, annexin A7 (ANXA7), p53, nuclear factor- $\kappa$ B p65 (NF- $\kappa$ B p65), reactive oxygen species (ROS) levels, and mitochondrial membrane potential were investigated. Our data indicated that treatment of EECP for 24 and $48 \mathrm{~h}$ induced both cells apoptosis obviously. Exposure to EECP significantly increased ANXA7 expression and ROS level, and NF- $\kappa$ B p65 level and mitochondrial membrane potential were depressed by EECP dramatically. The effects of EECP on p53 level were different in MCF-7 and MDA-MB-231 cells, which indicated that EECP exerted its antitumor effects in MCF-7 and MDA-MB-231 cells by inducing apoptosis, regulating the levels of ANXA7, p53, and NF- $\kappa \mathrm{B}$ p 65 , upregulating intracellular ROS, and decreasing mitochondrial membrane potential. Interestingly, EECP had little or small cytotoxicity on normal human umbilical vein endothelial cells (HUVECs). These results suggest that EECP is a potential alternative agent on breast cancer treatment.
\end{abstract}

\section{Introduction}

Propolis, a natural product and healthy food raw material, is collected by honeybees from various plants. It has been used since ancient times for its widely biological activities such as antibacterial, antiviral, antioxidant, anti-inflammatory, and antitumor $[1,2]$.

There are different types of propolis according to the location of its botanical origin and collecting season [3]. Based on Bankova classification, there are six main types of propolis, that is, poplar propolis, birch propolis, Brazilian green propolis, red propolis, pacific propolis, and Canarian propolis [4]. Chinese propolis is mainly classified as poplar-type and the predominant chemical compositions are flavonoids and phenolic compounds [5]. It exerts various biological activities including antitumor.

Recently, antitumor properties of propolis, the most remarkable activity, have been widely documented in various culture cell lines such as human leukemia (HL-60, CI41, U937), human colon cancer cells (SW480, HCT116), human cervical cancer (ME180, Hela), human glioblastoma cells (U87MG), human lung carcinoma (A549), human hepatocellular carcinoma (HepG2, SNU449), human pancreatic cancer (PANC-1, BxPC-3) cells, and mammary carcinoma (MCF7) [6-15]. However, the molecular mechanisms of Chinese propolis on antitumor effects have not been fully elucidated and need to be deeply clarified. Here we investigated the anticancer effects of Chinese propolis in MCF-7 (human breast cancer ER(+)) and MDA-MB-231 (human breast cancer ER (-)) cells and then studied the underlying molecular mechanisms of Chinese propolis on both breast cancer cells.

\section{Materials and Methods}

2.1. Materials. DMEM was obtained from Gibco BRL Co. (USA). Fetal bovine serum was from Hyclone Laboratories 
Inc. (USA). Acridine orange (AO) was from Amresco (USA). Hoechst 33258, $2^{\prime}, 7^{\prime}$-dichlorodihydrofluorescin (DCHF), JC1 , propidium iodide (PI), and sulforhodamine $B(\mathrm{SRB})$ were from Sigma Co. (USA). The antibodies against p53, ANXA7, NF- $\kappa$ B p $65, \beta$-actin, and horseradish peroxidase-conjugated secondary antibodies were from Santa Cruz Biotechnology (USA). Secondary antibodies for immunofluorescence, donkey anti-rabbit IgG Alexa Fluor-488, were purchased from Life Technologies (USA). All the other reagents were of ultrapure grade.

2.2. Preparation of Propolis Extracts. Propolis used in the present study was Chinese propolis and had been used in our previous study [16]. The main plant origin was poplar (Populus sp.). Samples were maintained at $-20^{\circ} \mathrm{C}$ before processing. Propolis sample was extracted with $95 \%$ ethanol at room temperature for $24 \mathrm{~h}$. The ethanol suspension was filtered under reduced pressure. The filter liquid was then concentrated in a rotary evaporator under reduced pressure at $40^{\circ} \mathrm{C}$ until it reached a constant weight and was later redissolved in ethanol. The ethanol-extracted Chinese propolis (EECP) had a brown color. The prepared propolis was stored under a dry condition at $4^{\circ} \mathrm{C}$.

To determine the constituents in EECP, we used highperformance liquid chromatography (HPLC) analysis with a photodiode array (PDA). EECP was dissolved in ethanol $(2 \mathrm{mg} / \mathrm{mL})$ to the injection of $10 \mu \mathrm{L}$ into the HPLC system. The HPLC system used was Agilent 1100 (Germany) with a $\mathrm{C} 18$ column $(4.6 \times 250 \mathrm{~mm}$ i.d., $5 \mu \mathrm{m})$ at $28^{\circ} \mathrm{C}$ with a detection wavelength at $280 \mathrm{~nm}$. The mobile phases consisted of methanol (A) and $0.1 \%$ phosphoric acid (B) at a flow rate of $1.0 \mathrm{~mL} / \mathrm{min}$.

2.3. Cell Cultures. The human breast cancer cells, MCF-7 and MDA-MB-231, were purchased from American Type Culture Collection (ATCC, USA). Human umbilical vein endothelial cells (HUVECs) were gifted by Atherosclerosis Research Institute of Taishan Medical University of China and purchased from ATCC. All cells were, respectively, cultured in DMEM medium, supplemented with $10 \%(\mathrm{v} / \mathrm{v})$ FBS and $100 \mathrm{U} / \mathrm{mL}$ of penicillin, $100 \mu \mathrm{g} / \mathrm{mL}$ streptomycin at $37^{\circ} \mathrm{C}$ under humidified $95-5 \%(\mathrm{v} / \mathrm{v})$ air and $\mathrm{CO}_{2}$.

2.4. Cell Viability Assay. Cells were seeded at the density of $4 \times 10^{4} / \mathrm{mL}$ into 96 -well cell culture plates and were treated with different concentrations of $\operatorname{EECP}(25,50,100$, and $200 \mu \mathrm{g} / \mathrm{mL}$ ). At 24 and $48 \mathrm{~h}$, cells were precipitated for $1 \mathrm{~h}$ at $4^{\circ} \mathrm{C}$ with $100 \mu \mathrm{L} 10 \%$ trichloroacetic acid and stained with SRB. The optical density was measured at $492 \mathrm{~nm}$ after reconstitution of the dye in $100 \mu \mathrm{L} 10 \mathrm{mM}$ Tris base. The viability (\%) was expressed as (OD of treated group/OD of control group) $\times 100 \%$. The viability of the control cells was set to $100 \%$.

2.5. Nuclear Fragmentation Assay. Nuclear fragmentation was detected by acridine orange staining. Briefly, at $48 \mathrm{~h}$, cells were stained with $5 \mu \mathrm{g} / \mathrm{mL} \mathrm{AO}$ at room temperature for

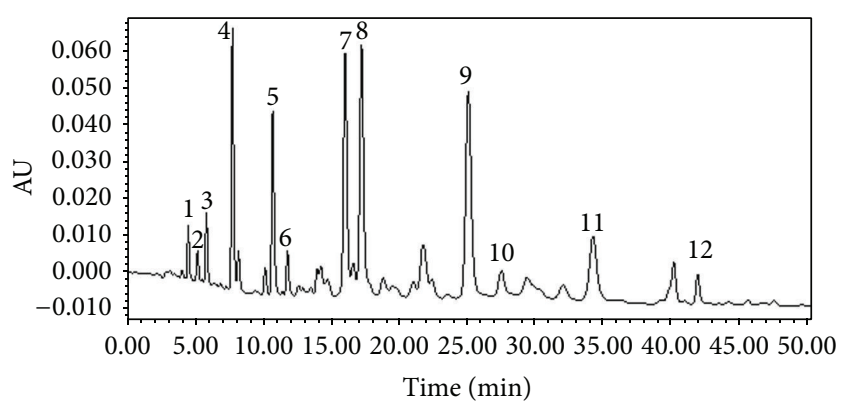

FIgURE 1: The constituents from ethanol-extracted Chinese propolis (EECP). 1. Caffeic acid; 2. p-coumaric acid; 3. ferulic acid 4. pinobanksin; 5. 7-hydroxy-5-methoxyflavanone; 6. kaempferol; 7. Pinocembrin; 8. pinobanksin 3-acetate; 9. chrysin; 10. caffeic acid phenethyl ester; 11. galangin; 12. tectochrysin.

$5 \mathrm{~min}$ and then were observed under a TE2000S fluorescence microscope (Nikon, Japan).

2.6. Hoechst 33258 Staining. Hoechst 33258 staining was used to observe apoptotic morphology. At $48 \mathrm{~h}$, cells in all groups were stained with $10 \mu \mathrm{g} / \mathrm{mL}$ Hoechst 33258 for 15 min. Cells were gently washed with PBS once. Nuclear condensation and fragmentation were observed under a TE2000S fluorescence microscope (Nikon, Japan).

2.7. Wound-Healing Assay. Cells were grown to $80 \%$ confluence in a 24 -well plate. The monolayers were scratched with a plastic tip, washed by PBS to remove floating cell debris, and then incubated in medium in the absence or presence of different concentration of EECP for $48 \mathrm{~h}$. Cell migration into the wound surface was determined under a TE2000S inverted microscope (Nikon, Japan). Migrated cells across the scratched lines were counted by Image-Pro Plus software (USA).

2.8. Immunofluorescence Microscopy Assay. As described in the previous report [17], MCF-7 and MDA-MB-231 cells treated with EECP were fixed in $4 \%$ paraformaldehyde $(\mathrm{w} / \mathrm{v})$ for $15 \mathrm{~min}$ at room temperature and blocked in 5\% donkey serum $(\mathrm{v} / \mathrm{v})$ and then incubated with primary antibodies overnight at $4^{\circ} \mathrm{C}$. Then cells were rinsed with $0.1 \mathrm{M}$ PBS three times and incubated with corresponding FITC-conjugated secondary antibodies $1 \mathrm{~h}$ at $37^{\circ} \mathrm{C}$. Cells were then rinsed three times with $0.1 \mathrm{M}$ PBS to eliminate the uncombined secondary antibody. Nuclei were counterstained with PI. A laser scanning confocal microscope (Olympus FV1200, Japan) was used for fluorescence detection. Analysis was made by the Image-Pro Plus software (USA). Images were representative of three independent experiments.

2.9. Western Blot Assay. After treatment with EECP, cells were lysed in lysis buffer at ice. Thirty micrograms of protein were separated by $12 \%$ SDS-PAGE and transferred onto 


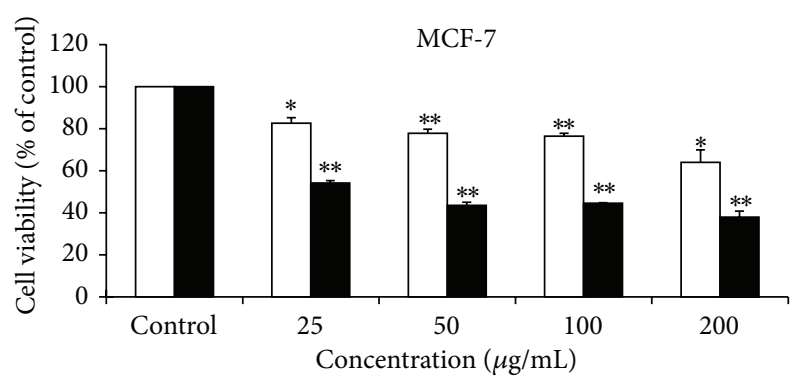

$24 \mathrm{~h}$

- $48 \mathrm{~h}$

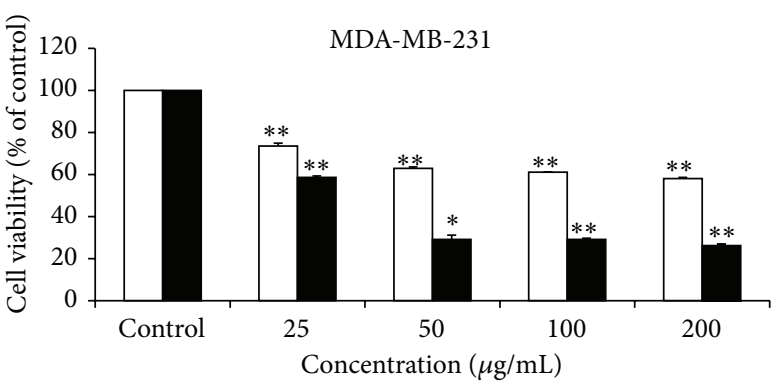

ㅁ $24 \mathrm{~h}$

- $48 \mathrm{~h}$

(a)

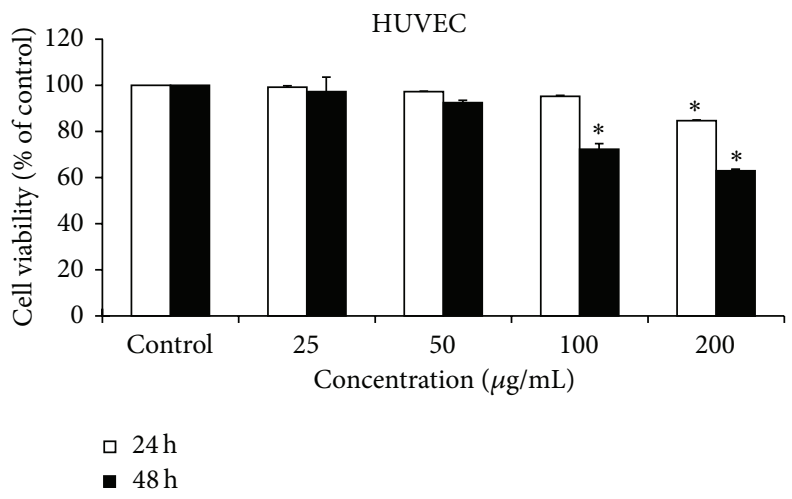

(c)

FIGURE 2: EECP decreased MCF-7 and MDA-MB-231 cells proliferation but had little/small effect on normal HUVECs. (a) EECP inhibited MCF-7 proliferation at 24 and $48 \mathrm{~h}$. (b) EECP inhibited MDA-MB-231 cells proliferation at 24 and $48 \mathrm{~h}$. (c) EECP had little effect on normal HUVECs viability under the concentration of $100 \mu \mathrm{g} / \mathrm{mL}\left({ }^{*} P<0.05,{ }^{* *} P<0.01\right.$ versus control, $\left.n=3\right)$. Data are means \pm S.E.M.

polyvinylidene difluoride (PVDF) membrane. The membrane was blocked with $5 \%(\mathrm{w} / \mathrm{v})$ nonfat dry milk in PBSTween 20 (PBST; $0.05 \%$ ) for $1 \mathrm{~h}$ and was incubated with primary antibody $\left(1: 1,000\right.$ in PBST) at $4^{\circ} \mathrm{C}$ overnight. After three washings in PBST, the PVDF membrane was incubated with appropriate horseradish peroxidase-conjugated secondary antibodies $(1: 5,000)$ for $1 \mathrm{~h}$ at room temperature. The immunoreactive bands were developed with ECL western blotting system. The relative quantity of proteins was analyzed by use of Quantity One software (Bio-Rad, Hercules, CA, USA).

2.10. Determination of Intracellular ROS Levels. Intracellular ROS level was measured with $2^{\prime}, 7^{\prime}$-dichlorodihydrofluorescein (DCHF), which could be rapidly oxidized into the highly fluorescent $2^{\prime}, 7^{\prime}$-dichlorofluorescein (DCF) in the presence of intracellular ROS [18]. We treated cells as mentioned above for $48 \mathrm{~h}$ then washed cells with basal DMEM medium for $5 \mathrm{~min}$ and incubated the cells with DCHF $1 \mathrm{~mL}$ at $37^{\circ} \mathrm{C}$ for $30 \mathrm{~min}$. After washing the cells three times with basal DMEM medium, the fluorescence was monitored with a confocal laser scanning microscope (Olympus FV1200, Japan) using excitation and emission wavelengths of $488 \mathrm{~nm}$. The amount of ROS was quantified by Image-Pro Plus software (USA).
The images were representative of three independent experiments.

2.11. Intracellular Mitochondrial Membrane Potential Assay. Fluorescence probe of JC-1 was used to test mitochondrial membrane potential. JC-1 exists as a monomer at low mitochondrial membrane potential and emits green fluorescence but forms aggregates and emits red fluorescence at high mitochondrial membrane potential [19]. Cells were treated for $48 \mathrm{~h}$ then washed with basal DMEM medium for $5 \mathrm{~min}$ and incubated with JC- $11 \mathrm{~mL}$ at $37^{\circ} \mathrm{C}$ for $15 \mathrm{~min}$. After washing the cells three times with basal DMEM medium, the fluorescence was monitored with a confocal laser scanning microscope (Olympus FV1200, Japan) using excitation and emission wavelengths of 488 and $546 \mathrm{~nm}$, respectively. Results were shown by ratio of red to green fluorescence as compared with the control; Image-Pro Plus software (USA) was used to analysis fluorescence intensity.

2.12. Statistical Analysis. Data are from at least three independent experiments and expressed as means \pm S.E.M. Statistical analysis involved the paired Student $t$ test and ANOVA with SPSS version 11.5. Differences were considered statistically significant at $P<0.05$. 


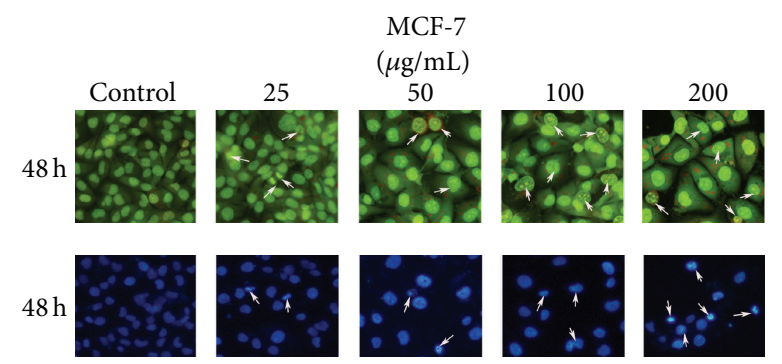

(a)

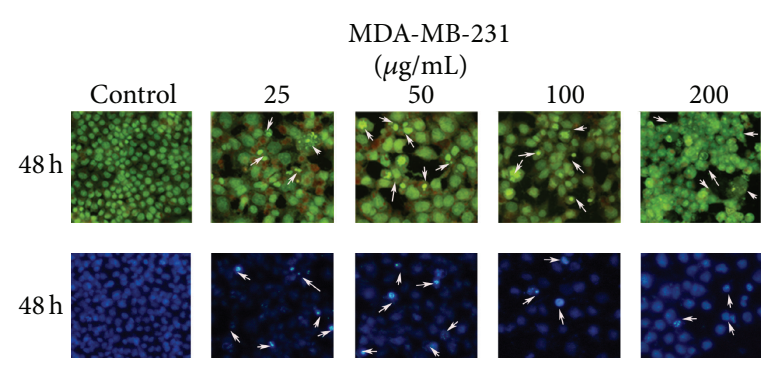

(b)

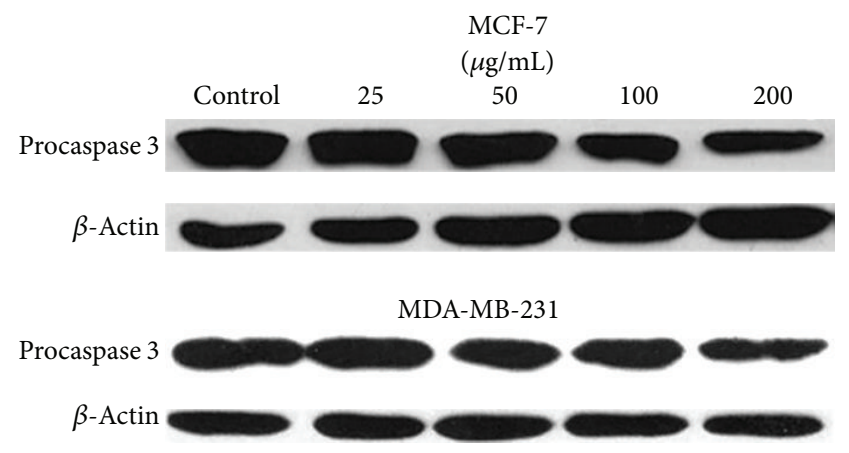

(c)

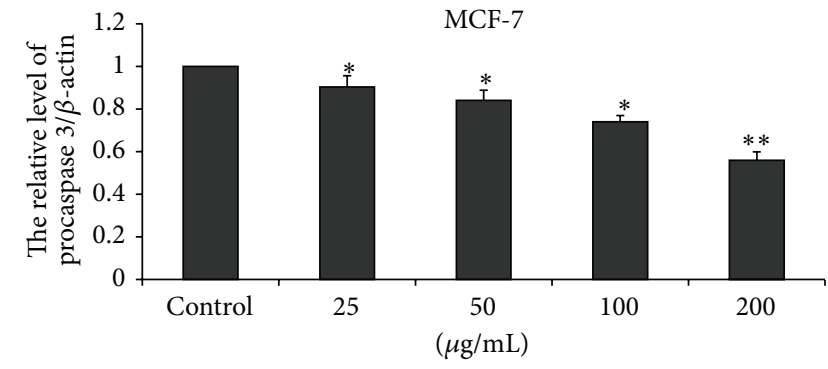

MDA-MB-231

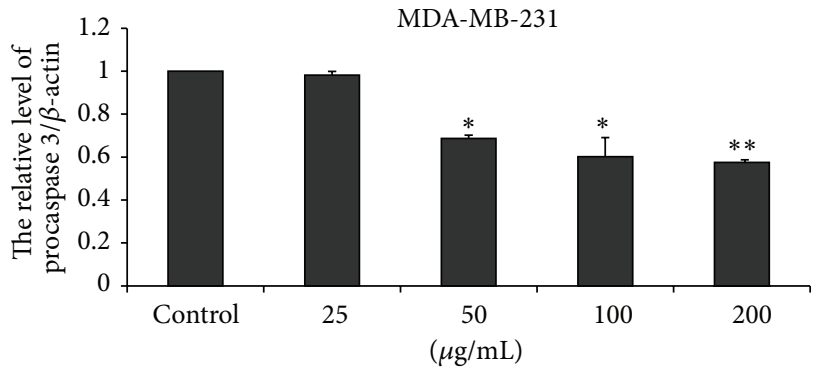

(d)

FIGURE 3: EECP induced apoptosis in MCF-7 and MDA-MB-231 cells. (a) Morphological changes of nuclei in MCF-7 cells by staining with acridine orange and Hoechst 33258 at $48 \mathrm{~h}(\times 200)$. (b) Morphological changes of nuclei in MDA-MB-231 cells by staining with acridine orange and Hoechst 33258 at $48 \mathrm{~h}(\times 200)$. (c) The levels of procaspase $3(35 \mathrm{KD})$ were detected by western blot at $24 \mathrm{~h}$. (d) The hemiquantification of procaspase 3 levels in MCF-7 and MDA-MB-231 cells $\left({ }^{*} P<0.05,{ }^{* *} P<0.01\right.$ versus control, $\left.n=3\right)$.

\section{Results}

3.1. Constituents of EECP. The main constituents identified in our sample are caffeic acid, $p$-coumaric acid, ferulic acid, pinobanksin, 7-hydroxy-5-methoxyflavanone, kaempferol, pinocembrin, pinobanksin 3-acetate, chrysin, caffeic acid phenethyl ester, galangin, and tectochrysin by HPLC analysis (Figure 1).

3.2. EECP Decreased MCF-7 and MDA-MB-231 Cells Proliferation but Had Little Effect on Normal HUVECs. We investigated the sensitivity of MCF-7 and MDA-MB-231 cells to $\operatorname{EECP}(25,50,100$, and $200 \mu \mathrm{g} / \mathrm{mL})$ using SRB assay at 24 and $48 \mathrm{~h}$. EECP significantly inhibited MCF-7 and MDAMB-231 cells proliferation in a dose- and time-dependent manner. Notably, the inhibitory effect of EECP on MDAMB-231 cells was higher than on MCF-7 cells $\left({ }^{*} P<0.05\right.$, ${ }^{* *} P<0.01$; Figures $2(\mathrm{a})$ and $\left.2(\mathrm{~b})\right)$.

We also investigated the effect of EECP on normal HUVECs viability, and the results showed that there was little effect on proliferation of normal HUVECs under the concentrations of $100 \mu \mathrm{g} / \mathrm{mL}$. However, EECP at concentration of $200 \mu \mathrm{g} / \mathrm{mL}$ had small cytotoxicity $\left({ }^{*} P<0.05\right.$; Figure $\left.2(\mathrm{c})\right)$.

\subsection{EECP Induced Apoptosis in MCF-7 and MDA-MB-231} Cells. Acridine orange and Hoechst 33258 staining results indicated that different concentrations of EECP evidently induced nuclear condensation and fragmentation of MCF7 and MDA-MB-231 cells in a dose-dependent manner. Importantly, nuclei of MDA-MB-231 cells treated with EECP $200 \mu \mathrm{g} / \mathrm{mL}$ were almost fragmentation (Figures 3(a) and $3(\mathrm{~b})$ ). In addition, we also tested procaspase 3 (35KD) by western blot at $24 \mathrm{~h}$. The results showed that caspase 3 was activated in MCF-7 and MDA-MB-231 cells treated with EECP (Figures 3(c) and 3(d)).

3.4. EECP Inhibited MDA-MB-231 Cells Migration. Roughly $70 \%$ of all patients dying of breast cancer have bone metastases [20]. Therefore, we also performed wounding-healing experiments to detect the effect of EECP on migration of 


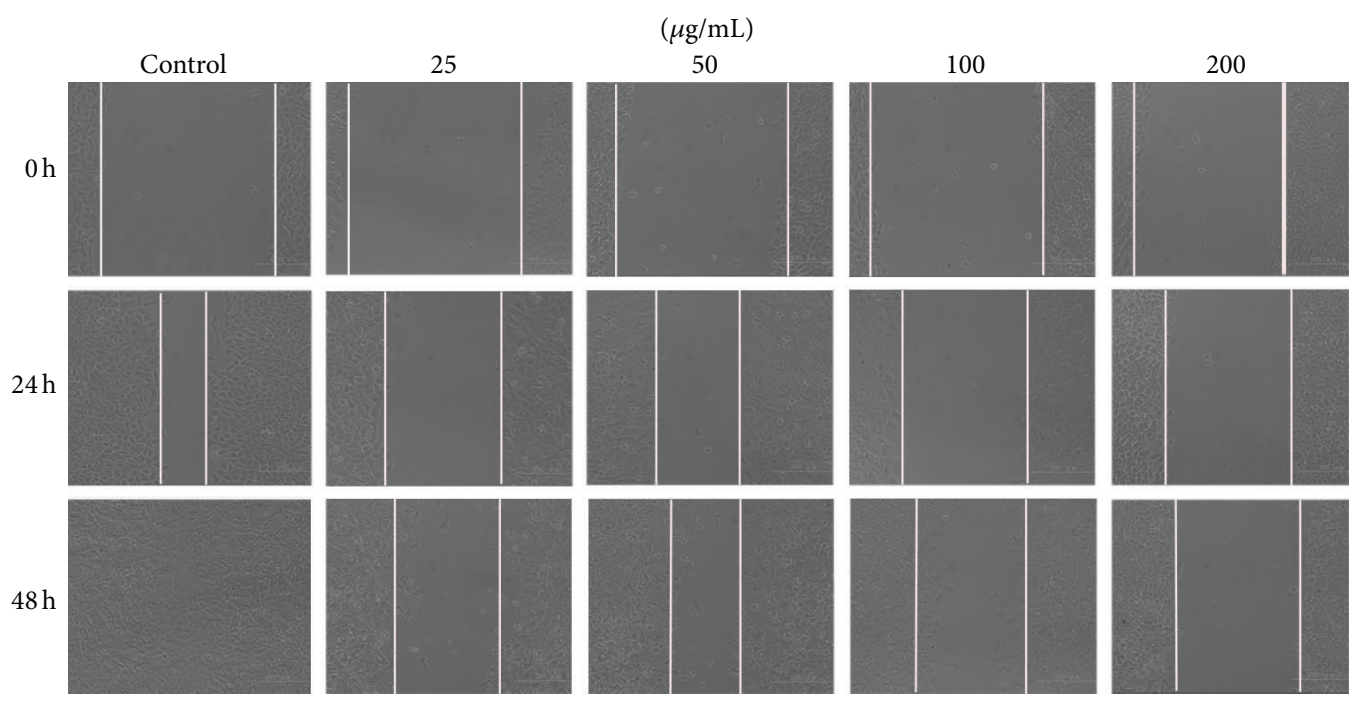

(a)

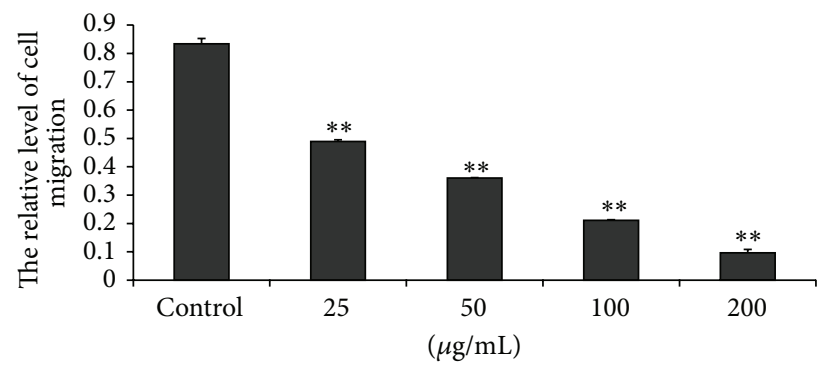

(b)

FIGURE 4: EECP inhibited MDA-MB-231 cells migration. (a) Cell migration micrographs obtained under a phase contrast microscope at 0 , 24 , and $48 \mathrm{~h}(\times 100)$. (b) Relative levels of cell migration $\left({ }^{* *} P<0.01\right.$ versus control, $\left.n=3\right)$.

MCF-7 and MDA-MB-231 cells. EECP significantly inhibited MDA-MB-231 cells migration in a dose-dependent manner at $48 \mathrm{~h}\left({ }^{* *} P<0.01\right.$; Figure 4$)$, whereas inhibitory effect of EECP on migration of MCF-7 cells was not significant (data were not shown).

3.5. EECP Regulated the Levels of ANXA7, p53, and NF- $\kappa B$ p65 in MCF-7 and MDA-MB-231 Cells. EECP significantly upregulated the expression of ANXA7 and downregulated NF- $\kappa$ B p 65 level in a dose-dependent manner by western blot and immunofluorescent assay in MCF-7 and MDA-MB231 cells. Furthermore, the translocation of NF- $\kappa$ B p 65 from cytoplasm to nuclei was also inhibited by EECP in both cells. The effect of EECP on p53 level in MCF-7 and in MDA-MB-231 cells was different. p53 level was significantly increased in MCF-7 cells. However, in MDA-MB-231 cells, EECP evidently inhibited p53 level $\left({ }^{*} P<0.05,{ }^{* *} P<0.01\right.$; Figures 5 and 6).

3.6. EECP Increased ROS Level in MCF-7 and MDA-MB231 Cells. EECP at concentration of $25-200 \mu \mathrm{g} / \mathrm{mL}$ significantly increased ROS level in MCF-7 cells, whereas, in MDA-MB-231 cells, EECP at concentration of $50-200 \mu \mathrm{g} / \mathrm{mL}$ evidently increased ROS level $\left({ }^{*} P<0.05,{ }^{* *} P<0.01\right.$; Figure 7).

3.7. EECP Reduced Mitochondrial Membrane Potential in MCF-7 and MDA-MB-231 Cells. The mitochondrial membrane potential sensor JC-1 was used to determine the mitochondrial function. As shown in Figure 7, EECP significantly decreased mitochondrial membrane potential in a dosedependent manner in MCF-7 and MDA-MB-231 cells at $48 \mathrm{~h}$. Note that the decreased level of mitochondrial membrane potential in MDA-MB-231 cells was higher than that in MCF7 cells $\left({ }^{* *} P<0.01\right.$; Figure 8$)$.

\section{Discussion}

In propolis, there is usually a variety of chemical compounds, such as polyphenols, terpenoids, steroids, and amino acid. Propolis samples obtained from different plants are composed of different chemical compounds. Chinese propolis is mainly classified as poplar-type and the predominant chemical constituents are flavonoids and phenolic compounds, and their percentage ranges from $35 \%$ to $50 \%$ [21]. Our results from HPLC also indicate that the major 


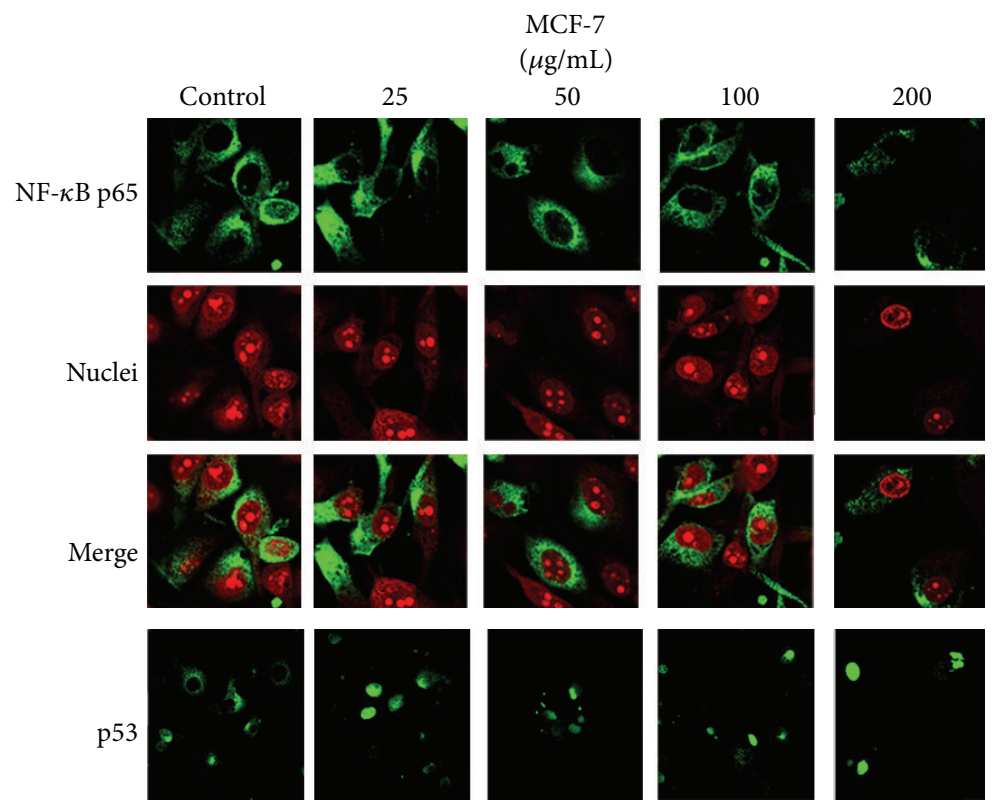

(a)

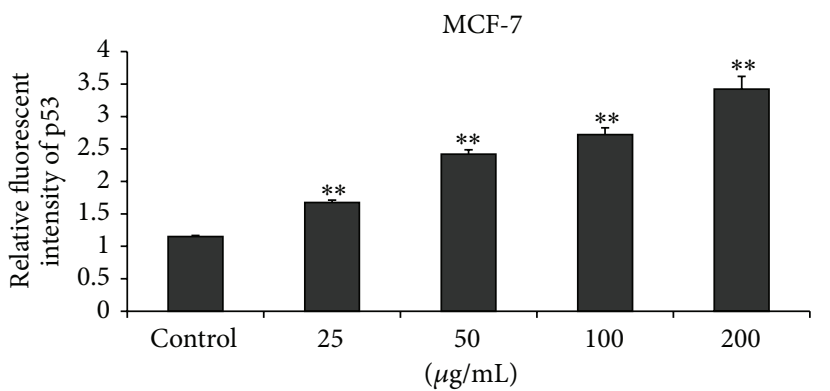

(b)

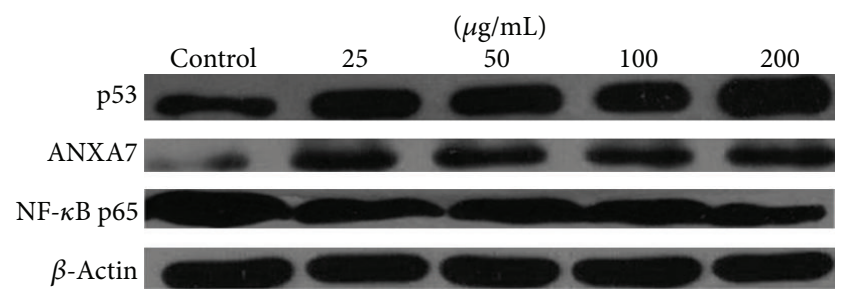

(d)

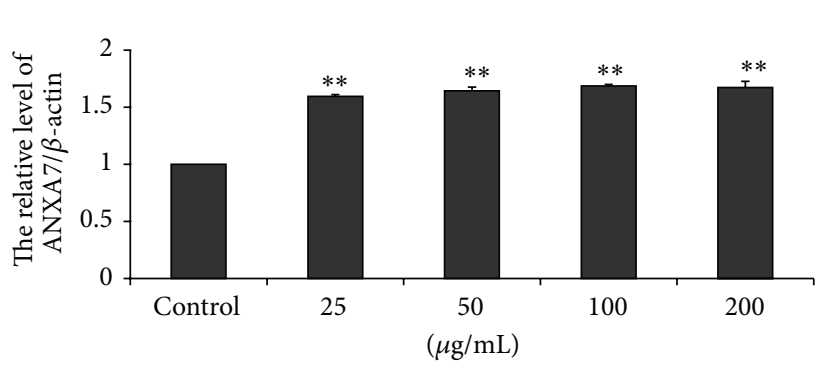

(f)

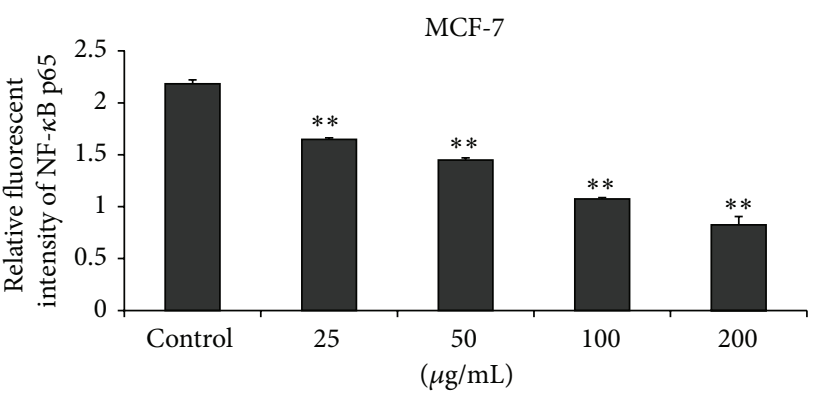

(c)

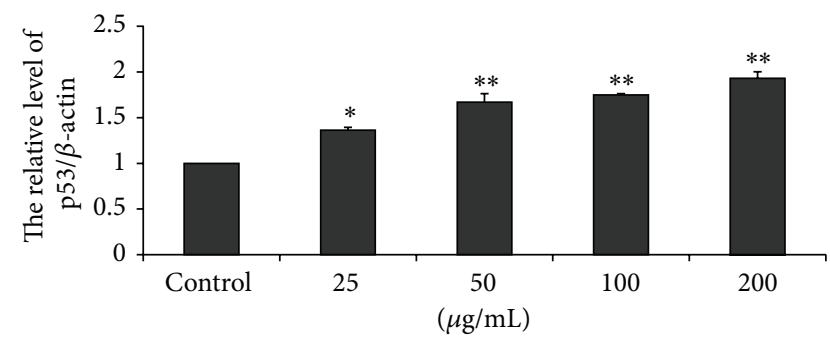

(e)

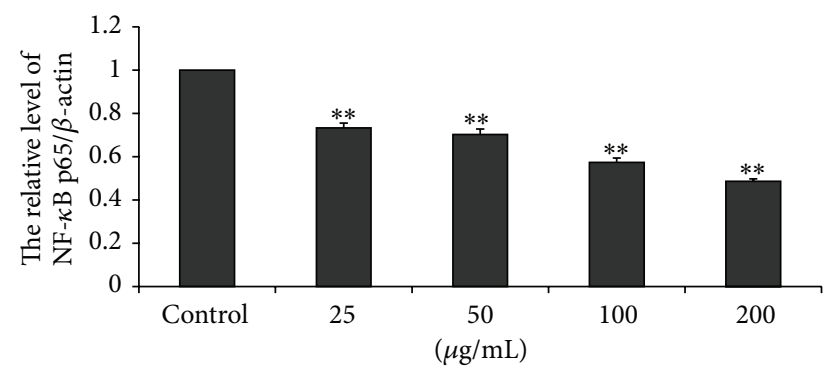

(g)

Figure 5: EECP regulated the levels of ANXA7, p53, and NF- $\kappa$ B p65 in MCF-7 cells. (a) Fluorescent micrographs obtained at $48 \mathrm{~h}(\times 400)$. Nuclei were counterstained with PI. (b) and (c) The relative fluorescence intensity of NF- $\kappa$ B p65 and p53 in MCF-7 cells. (d) The levels of p53, ANXA7, and NF- $\kappa$ B p 65 were detected by western blot at 48 h. (e), (f), and (g) The hemiquantification of p53, ANXA7, and NF- $\kappa$ B p65 levels in MCF-7 cells $\left({ }^{*} P<0.05,{ }^{* *} P<0.01\right.$ versus control, $\left.n=3\right)$. 


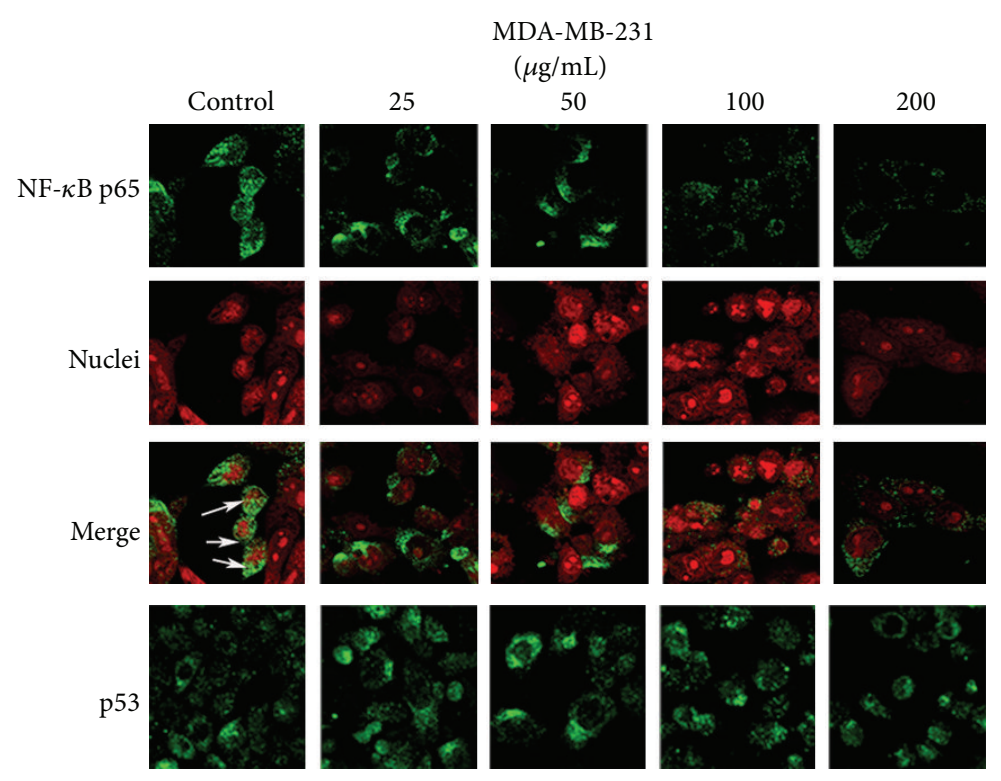

(a)

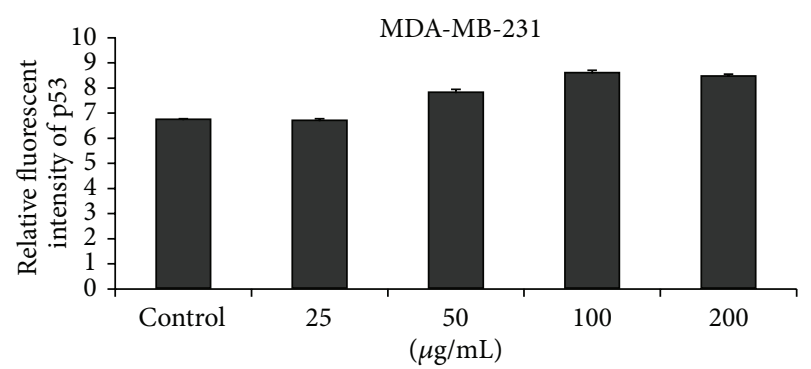

(b)

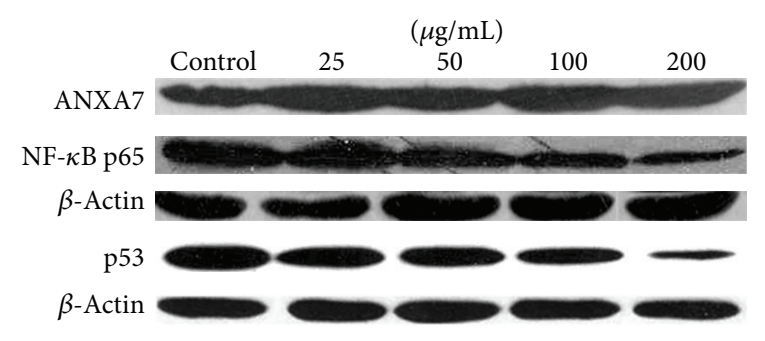

(d)

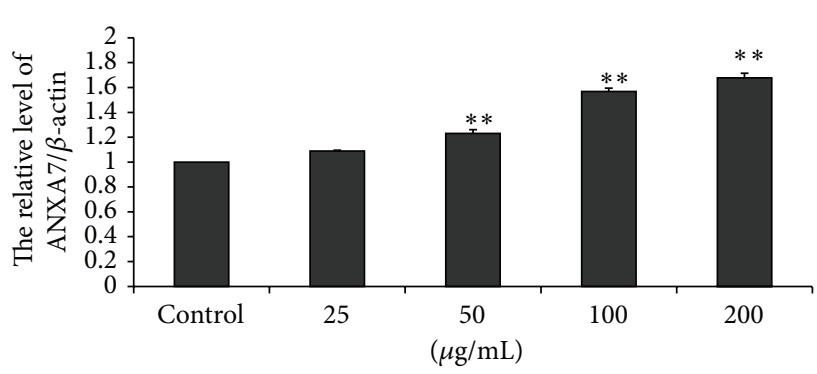

(f)

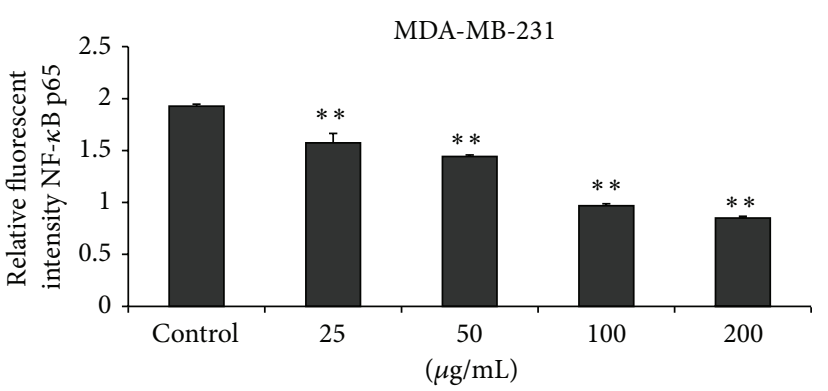

(c)

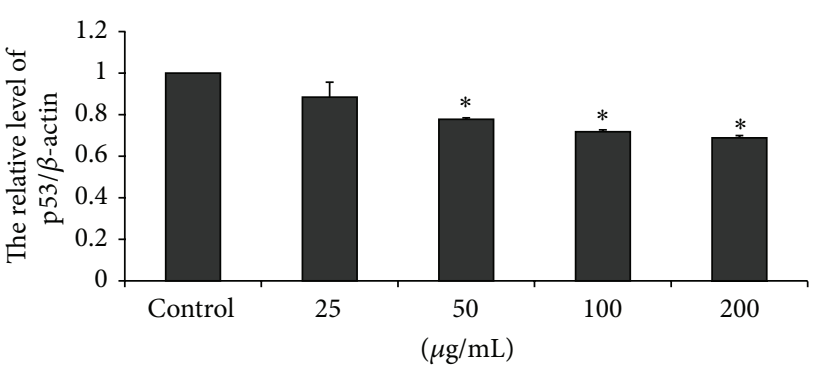

(e)

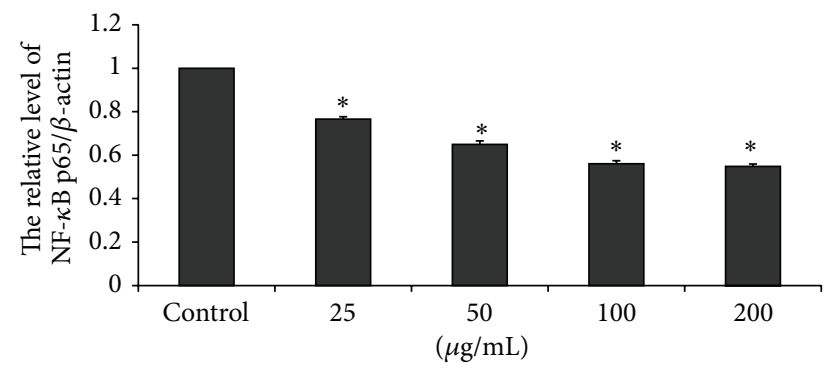

(g)

Figure 6: EECP regulated the levels of ANXA7, p53, and NF- $\kappa$ B p65 in MDA-MB-231 cells. (a) Fluorescent micrographs obtained at $48 \mathrm{~h}$ $(\times 400)$. (b) and (c) The relative fluorescence intensity of NF- $\kappa$ B p65 and p53 in MDA-MB-231 cells. (d) The levels of ANXA7 and NF- $\kappa$ B p65 were detected by western blot at $48 \mathrm{~h}$; the level of p53 was detected by western blot at $24 \mathrm{~h}$. (e), (f), and (g) The hemiquantification of p53, ANXA7, and NF- $\kappa$ B p65 levels in MDA-MB-231 cells $\left({ }^{*} P<0.05,{ }^{* *} P<0.01\right.$ versus control, $\left.n=3\right)$. 


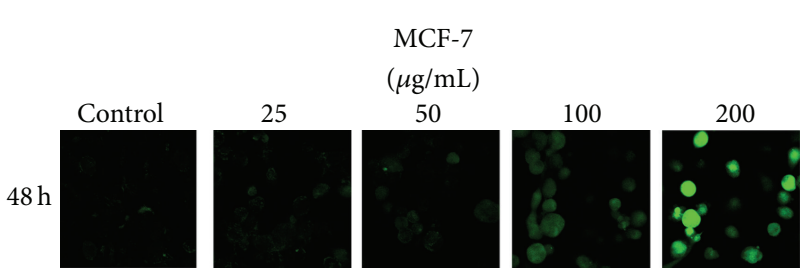

(a)

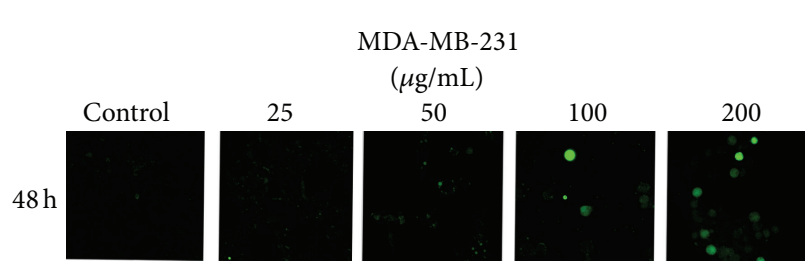

(c)

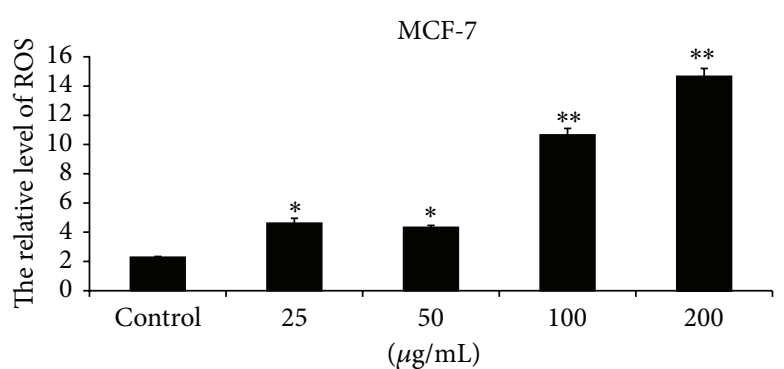

(b)

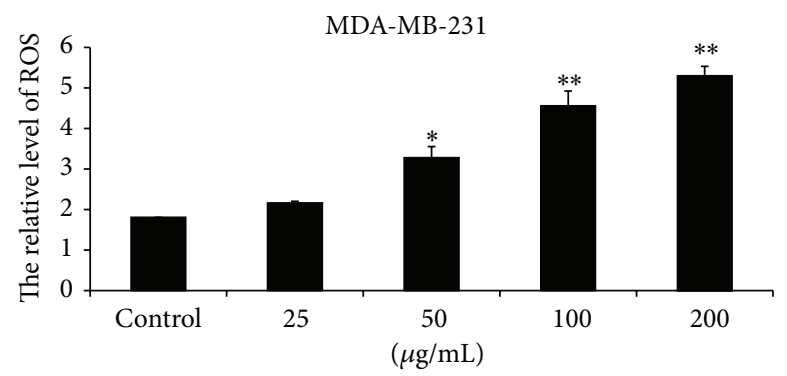

(d)

FiguRE 7: EECP increased ROS level in MCF-7 and MDA-MB-231 cells. (a) Fluorescent micrographs of MCF-7 cells obtained at $48 \mathrm{~h}(\times 200)$. (b) Relative quantity of ROS in MCF-7 cells. (c) Fluorescent micrographs of MDA-MB-231 cells obtained at $48 \mathrm{~h}(\times 200)$. (d) Relative quantity of ROS in MDA-MB-231 cells. Values represent the relative fluorescent intensity determined by laser scanning confocal microscopy $\left({ }^{*} P<0.05\right.$, ${ }^{* *} P<0.01$ versus control, $n=3$ ).

chemical constituents of EECP are polyphenolic/flavonoids. And caffeic acid phenethyl ester, caffeic acid, galangin, chrysin, kaempferol, pinobanksin, and pinocembrin are the major compounds. Furthermore, accumulating evidence has indicated that polyphenolic/flavonoids may serve as a potent adjunct to chemotherapy and radiotherapy in the treatment of cancers [22-24].

Breast cancer ranks among the most common malignant tumors afflicting women worldwide [25]. In this study we investigated the antitumor activities of EECP in MCF-7 and MDA-MB-231 cells. Our results showed that EECP potentially exerted its antitumor effect by inhibiting cell proliferation, inducing apoptosis, inhibiting cell migration, regulating ANXA7 and p53 levels, downregulating NF- $\kappa$ B p65 level and inhibiting its translocation from cytoplasm to nuclei, and increasing intracellular ROS level, decreasing mitochondrial membrane potential. Besides these, EECP had little or small effect on normal HUVECs. Interestingly, MDAMB-231 cells were more sensitive to EECP than MCF-7 cells.

The vascular endothelium cells play a critical role in the physiological and pathological progress for their location between the intravascular compartment and extravascular tissues [17]. Endothelial cells are the primary target for many chemical agents. Many anticancer chemical agents cannot be used in clinic for their cytotoxicity on endothelial cells. Here we found that EECP under concentration $100 \mu \mathrm{g} / \mathrm{mL}$ had good antitumor activity but had little cytotoxicity on normal HUVECs, and concentration of EECP $200 \mu \mathrm{g} / \mathrm{mL}$ had some small toxicity on HUVECs, which indicated the low toxicity of EECP when used as anticancer agent.
Cancer metastasis is the leading cause of mortality in patients with breast cancer. Metastasis is multistep process. MDA-MB-231 breast cancer cells, a highly metastatic human breast carcinoma cell line, are widely used as a model to study breast cancer cell metastasis. Here we found that EECP $25-200 \mu \mathrm{g} / \mathrm{mL}$ remarkably inhibited MDA-MB-231 cells migration, which indicated the good ability of EECP on inhibiting breast cancer cells metastasis.

ANXA7, a member of the annexin family of calciumdependent phospholipid binding proteins, codes for $\mathrm{Ca}^{2+}$ dependent GTPase, which involves several different roles in autophagy, exocytosis, carcinogenesis, and tumor suppression [26-28]. Recently, it is described as a candidate tumor suppressor gene for prostate cancer [29]. Human ANXA7 has been mapped to tumor susceptibility locus 10q21 with 35\% loss of heterozygosity in prostate and breast cancer indicating its possible tumor suppressive function [30]. Srivastava et al. (2001) indicated that ANXA7 could be a biomarker in the progression of breast cancer [31]. In present study, we found that EECP significantly upregulated ANXA7 level in MCF-7 and MDA-MB-231 cells. This is the first time indicating the effect of propolis on ANXA7 in breast cancer cells, which might be a new target of propolis on antitumor study and treatment.

$\mathrm{p} 53$, another tumor suppressor protein, is a central target of inactivation in human cancer and a key regulator of genotoxic stress-induced growth arrest or apoptosis [32]. We previously reported that both Chinese propolis and Brazilian green propolis affected p53 level in HUVECs with nutrition deprivation $[16,33]$. MCF-7 has a wild-type p53; here we 


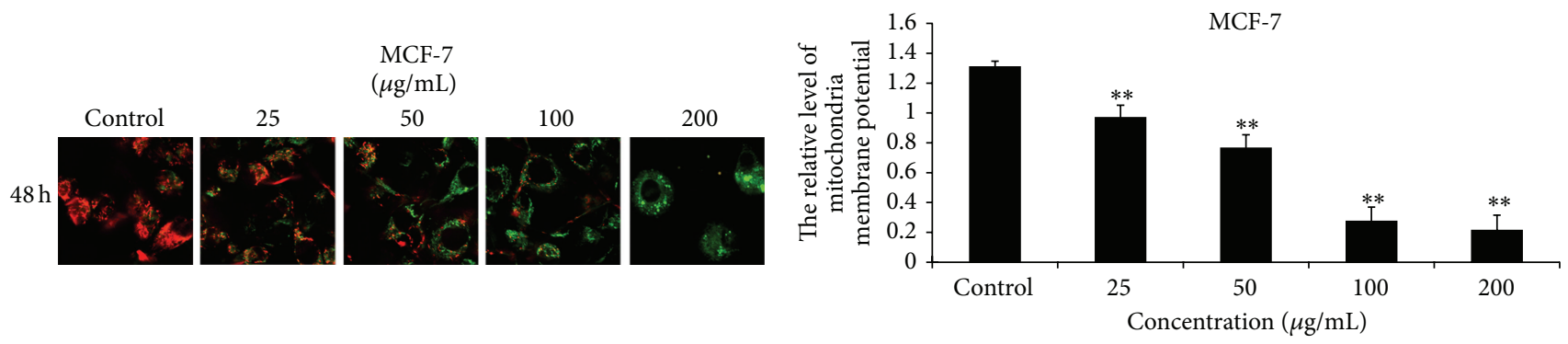

(a)

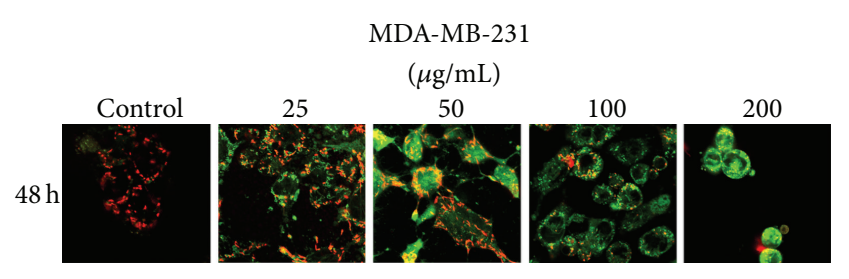

(c)

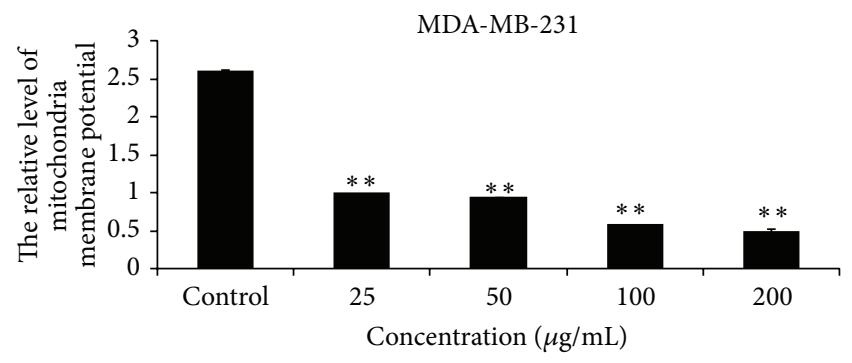

(d)

FIGURE 8: EECP reduced mitochondrial membrane potential in MCF-7 and MDA-MB-231 cells. (a) Fluorescent micrographs of MCF-7 cells obtained at $48 \mathrm{~h}(\times 400)$. (b) Relative quantity of mitochondrial membrane potential in MCF-7 cells. (c) Fluorescent micrographs of MDAMB-231 cells obtained at $48 \mathrm{~h}(\times 400)$. (d) Relative quantity of mitochondrial membrane potential in MDA-MB-231 cells. Values represent the relative fluorescent intensity determined by laser scanning confocal microscopy $\left({ }^{* *} P<0.01\right.$ versus control, $\left.n=3\right)$.

found that EECP higher $25 \mu \mathrm{g} / \mathrm{mL}$ significantly upregulated p53 level to induce apoptosis. However, MDA-MB-231 has a high level of a mutant p53, which contributes to the suppression of apoptosis in human breast cancer cells. In current study, we found that the effect of EECP on mutanttype p53 was complex and was dose-dependent. p53 level was inhibited with the increase of concentration by western blot assay. However, these changes could not be tested by immunofluorescence microscopy assay at $24 \mathrm{~h}$ for there was a high level of mutant p53-expressing in MDA-MB-231. Taken together, EECP exerts its antitumor effect through regulating p53 level.

The NF- $\kappa \mathrm{B}$ signal transduction pathway is deregulated in a variety of human cancers $[34,35]$. In most types of cancer cells, NF- $\kappa \mathrm{B}$ is constitutively active. Blocking NF- $\kappa \mathrm{B}$ has been shown to stop tumor cells from proliferating, to die, or to become more sensitive to the action of antitumor agents, especially antioxidants [36]. Therefore, agents capable of downmodulating the activation of NF- $\kappa \mathrm{B}$ have a potential for use in therapeutic interventions [37]. Here we found that EECP downregulated the activation of NF- $\kappa \mathrm{B}$ p65, a subunit of NF- $\kappa \mathrm{B}$, and inhibited its translocation from cytoplasm to nuclear to activate in MCF-7 and MDA-MB-231 cells, which indicated that EECP could become a useful antitumor agent.

Accumulating evidence has demonstrated that ROS are important signals in the regulation of diverse cellular functions. High levels of ROS induce oxidative stress, leading to a number of different diseases, including cancer [38]. However, recent studies indicated that high levels ROS induce apoptosis by triggering proapoptotic signaling molecules to antitumor
[39]. And we previously found that a high concentration of Brazilian propolis extract induced HUVECs apoptosis with ROS level increase, and at a low concentration propolis protected HUVECs by decreasing ROS level [33]. These findings taken together, it appears that propolis plays a dual role on ROS depending on concentrations: at high concentration, it exerts a prooxidant effect; at low concentration, it can also act as an antioxidant by scavenging free radicals. In present study, EECP induced MCF-7 and MDA-MB-231 cells apoptosis with ROS increase in a dose-dependent manner. EECP may therefore exert prooxidant effect in breast cancer cells.

The decrease of mitochondrial membrane potential would lead to the release of cytochrome $c$ to activate caspase to initiate apoptotic signaling pathway [40]. Mitochondria are the most important intracellular source of ROS, and elevated ROS levels can also decrease mitochondrial membrane potential [33]. Here, we found that EECP decreased mitochondrial membrane potential in MCF-7 and MDAMB-231 cells. From this viewpoint, we deduced that EECP induced apoptosis in MCF-7 and MDA-MB-231 cells were ROS-dependent mitochondrial pathway.

In conclusion, our results suggest that EECP and its polyphenolic/flavonoid components exert antitumor effects mainly through inducing apoptosis of breast cancer cells. The involved mechanisms commonly contain ANXA7 and p53 proteins regulating, NF- $\kappa \mathrm{B}$ inhibition, and regulation of ROS and mitochondrial membrane potential. Attractively, EECP has non-/low toxicity to normal cells because of its selective toxicities to tumor cells. So it is believed that propolis may become an attractive and promising agent for breast cancer 
treatment. However, further research is needed to clarify precise targets of propolis in breast cancer cells.

\section{Conflict of Interests}

The authors declare no conflict of interest regarding the publication of this paper.

\section{Authors' Contribution}

Hongzhuan Xuan and Zhen Li contributed equally to this work.

\section{Acknowledgments}

This work was supported by the Grants from the National Natural Science Foundation of China (nos. 31201860 and 31272512), Shandong Provincial Natural Science Foundation of China (no. ZR2012CQ003), the Modern Agroindustry Technology Research System from the Ministry of Agriculture of China (CARS-45), and the College Student Innovation Foundation of Liaocheng University, China (nos. SF2013279, SF2013282, and SF2013292).

\section{References}

[1] J. M. Sforcin and V. Bankova, "Propolis: is there a potential for the development of new drugs?" Journal of Ethnopharmacology, vol. 133, no. 2, pp. 253-260, 2011.

[2] V. C. Toreti, H. H. Sato, G. M. Pastore, and Y. K. Park, "Recent progress of propolis for its biological and chemical compositions and its botanical origin," Evidence-Based Complementary and Alternative Medicine, vol. 2013, Article ID 697390, 13 pages, 2013.

[3] V. Bankova, "Chemical diversity of propolis and the problem of standardization," Journal of Ethnopharmacology, vol. 100, no. 12, pp. 114-117, 2005.

[4] V. Bankova, "Recent trends and important developments in propolis research," Evidence-Based Complementary and Alternative Medicine, vol. 2, no. 1, pp. 29-32, 2005.

[5] L. P. Sun, A. L. Chen, H. C. Hung et al., "Chrysin: a histone deacetylase 8 inhibitor with anticancer activity and a suitable candidate for the standardization of Chinese propolis," Journal of Agricultural and Food Chemistry, vol. 60, pp. 11748-11758, 2012.

[6] K. Aso, S. Kanno, T. Tadano, S. Satoh, and M. Ishikawa, "Inhibitory effect of propolis on the growth of human leukemia U937," Biological and Pharmaceutical Bulletin, vol. 27, no. 5, pp. 727-730, 2004.

[7] S. Mishima, Y. Narita, S. Chikamatsu et al., "Effects of propolis on cell growth and gene expression in HL-60 cells," Journal of Ethnopharmacology, vol. 99, no. 1, pp. 5-11, 2005.

[8] S. M. Alencar, T. L. C. Oldoni, M. L. Castro et al., "Chemical composition and biological activity of a new type of Brazilian propolis: red propolis," Journal of Ethnopharmacology, vol. 113, no. 2, pp. 278-283, 2007.

[9] S. Awale, F. Li, H. Onozuka, H. Esumi, Y. Tezuka, and S. Kadota, "Constituents of Brazilian red propolis and their preferential cytotoxic activity against human pancreatic PANC-1 cancer cell line in nutrient-deprived condition," Bioorganic and Medicinal Chemistry, vol. 16, no. 1, pp. 181-189, 2008.

[10] S. M. Messerli, M. Ahn, K. Kunimasa et al., "Artepillin C (ARC) in Brazilian green propolis selectively blocks oncogenic PAK1 signaling and suppresses the growth of NF tumors in mice," Phytotherapy Research, vol. 23, no. 3, pp. 423-427, 2009.

[11] C. N. Chen, C. J. Hsiao, S. S. Lee et al., "Chemical modification and anticancer effect of prenylated flavanones from Taiwanese propolis," Natural Product Research, vol. 26, pp. 116-124, 2012.

[12] G. C. Chan, K. W. Cheung, and D. M. Sze, "The immunomodulatory and anticancer properties of propolis," Clinical Reviews in Allergy \& Immunology, vol. 44, pp. 262-273, 2013.

[13] T. K. Ha, M. E. Kim, J. H. Yoon, S. J. Bae, J. Yeom, and J. S. Lee, "Galangin induces human colon cancer cell death via the mitochondrial dysfunction and caspase-dependent pathway," Experimental Biology and Medicine, vol. 238, pp. 1047-1054, 2013.

[14] R. Markiewicz-Zukowska, M. H. Borawska, A. Fiedorowicz, S. K. Naliwajko, D. Sawicka, and H. Car, "Propolis changes the anticancer activity of temozolomide in U87MG human glioblastoma cell line," BMC Complementary and Alternative Medicine, vol. 13, article 50, 2013.

[15] F. Yang, H. Jin, J. Pi et al., "Anti-tumor activity evaluation of novel chrysin-organogermanium(IV) complex in MCF-7 cells," Bioorganic \& Medicinal Chemistry Letters, vol. 23, pp. 55445551, 2013.

[16] H. Xuan, R. Zhu, Y. Li, and F. Hu, "Inhibitory effect of chinese propolis on phosphatidylcholine-specific phospholipase C activity in vascular endothelial cells," Evidence-Based Complementary and Alternative Medicine, vol. 2011, Article ID 985278, 8 pages, 2011.

[17] N. Meng, L. Wu, J. Gao et al., "Lipopolysaccharide induces autophagy through BIRC2 in human umbilical vein endothelial cells," Journal of Cellular Physiology, vol. 225, no. 1, pp. 174-179, 2010.

[18] N. Suematsu, H. Tsutsui, J. Wen et al., "Oxidative stress mediates tumor necrosis factor- $\alpha$-induced mitochondrial DNA damage and dysfunction in cardiac myocytes," Circulation, vol. 107, no. 10, pp. 1418-1423, 2003.

[19] H. Izuta, M. Shimazawa, S. Tazawa, Y. Araki, S. Mishima, and H. Hara, "Protective effects of Chinese propolis and its component, chrysin, against neuronal cell death via inhibition of mitochondrial apoptosis pathway in SH-SY5Y cells," Journal of Agricultural and Food Chemistry, vol. 56, no. 19, pp. 89448953, 2008

[20] A. Jemal, R. Siegel, E. Ward, Y. Hao, J. Xu, and M. J. Thun, "Cancer statistics, 2009," CA Cancer Journal for Clinicians, vol. 59, no. 4, pp. 225-249, 2009.

[21] N. Oršolić and I. Bašić, "Cancer chemoprevention by propolis and its polyphenolic compounds in experimental animals," Recent Progress in Medicinal Plants, vol. 17, pp. 55-113, 2007.

[22] D. Lamoral-Theys, L. Pottier, F. Dufrasne et al., "Natural polyphenols that display anticancer properties through inhibition of kinase activity," Current Medicinal Chemistry, vol. 17, no. 9, pp. 812-825, 2010.

[23] N. Oršolić, A. Horvat Knežević, L. Šver, S. Terzić, and I. Bašić, "Immunomodulatory and antimetastatic action of propolis and related polyphenolic compounds," Journal of Ethnopharmacology, vol. 94, pp. 307-315, 2004.

[24] N. Oršolić, "A review of propolis antitumor action in vivo and in vitro," Journal of ApiProduct and ApiMedical Science, vol. 2, no. 1, pp. 1-20, 2010. 
[25] L. Wang, Z. Dong, B. Huang et al., "Distinct patterns of autophagy evoked by two benzoxazine derivatives in vascular endothelia cells," Autophagy, vol. 6, no. 8, pp. 1115-1124, 2010.

[26] H. Li, S. Huang, S. Wang et al., "Relationship between annexin A7 and integrin $\beta 4$ in autophagy," The International Journal of Biochemistry \& Cell Biology, vol. 45, no. 11, pp. 2605-2611, 2013.

[27] H. Li, S. Huang, S. Wang et al., "Targeting annexin A7 by a small molecule suppressed the activity of phosphatidylcholinespecific phospholipase $C$ in vascular endothelial cells and inhibited atherosclerosis in apolipoprotein $\mathrm{E}(-) /(-)$ ice," Cell Death \& Disease, vol. 4, article e806, 2013.

[28] H. Li, N. Liu, S. Wang et al., "Identification of a small molecule targeting annexin A7," Biochimica et Biophysica Acta, vol. 1833, pp. 2092-2099, 2013.

[29] M. Srivastava, L. Bubendorf, V. Srikantan et al., "Anx7, a candidate tumor suppressor gene for prostate cancer," Proceedings of the National Academy of Sciences of the United States of America, vol. 98, no. 8, pp. 4575-4580, 2001.

[30] M. Srivastava, C. Montagna, X. Leighton et al., "Haploinsufficiency of Anx7 tumor suppressor gene and consequent genomic instability promotes tumorigenesis in the Anx7(+/-) mouse," Proceedings of the National Academy of Sciences of the United States of America, vol. 100, no. 2, pp. 14287-14292, 2003.

[31] M. Srivastava, L. Bubendorf, L. Nolan et al., "ANX7 as a biomarker in prostate and breast cancer progression," Disease Markers, vol. 17, no. 2, pp. 115-120, 2001.

[32] O. Karni-Schmidt, A. Zupnick, M. Castillo et al., "p53 is localized to a sub-nucleolar compartment after proteasomal inhibition in an energy-dependent manner," Journal of Cell Science, vol. 121, no. 24, pp. 4098-4105, 2008.

[33] H. Xuan, J. Zhao, J. Miao, Y. Li, Y. Chu, and F. Hu, "Effect of Brazilian propolis on human umbilical vein endothelial cell apoptosis," Food and Chemical Toxicology, vol. 49, no. 1, pp. 7885, 2011.

[34] T. Lu and G. R. Stark, "Cytokine overexpression and constitutive NFאB in cancer," Cell Cycle, vol. 3, no. 9, pp. 1114-1117, 2004.

[35] X. Zhang, B. Jin, and C. Huang, “The PI3K/Akt pathway and its downstream transcriptional factors as targets for chemoprevention," Current Cancer Drug Targets, vol. 7, no. 4, pp. 305-316, 2007.

[36] R. O. Escárcega, S. Fuentes-Alexandro, M. García-Carrasco, A. Gatica, and A. Zamora, "The transcription factor nuclear factorkappa B and cancer," Clinical Oncology, vol. 19, no. 2, pp. 154-161, 2007.

[37] Y. K. Choi, S. G. Cho, S. M. Woo et al., "Saussurea lappa clarkederived costunolide prevents TNF alpha-induced breast cancer cell migration and invasion by inhibiting NF-kappa B activity," Evidence-Based Complementary and Alternative Medicine, vol. 2013, Article ID 936257, 10 pages, 2013.

[38] P. Storz, "Reactive oxygen species in tumor progression," Frontiers in Bioscience, vol. 10, no. 2, pp. 1881-1896, 2005.

[39] Y. Wang, Q. Tang, S. Jiang, M. Li, and X. Wang, "Anti-colorectal cancer activity of macrostemonoside A mediated by reactive oxygen species," Biochemical and Biophysical Research Communications, vol. 441, no. 4, pp. 825-830, 2013.

[40] R. Singh, N. K. Avliyakulov, M. Braga et al., "Proteomic identification of mitochondrial targets of arginase in human breast cancer," PLoS ONE, vol. 8, Article ID e79242, 2013. 


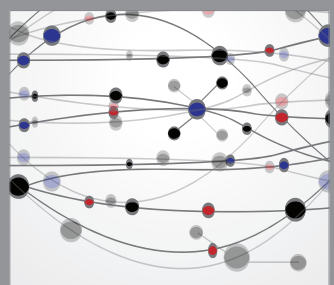

The Scientific World Journal
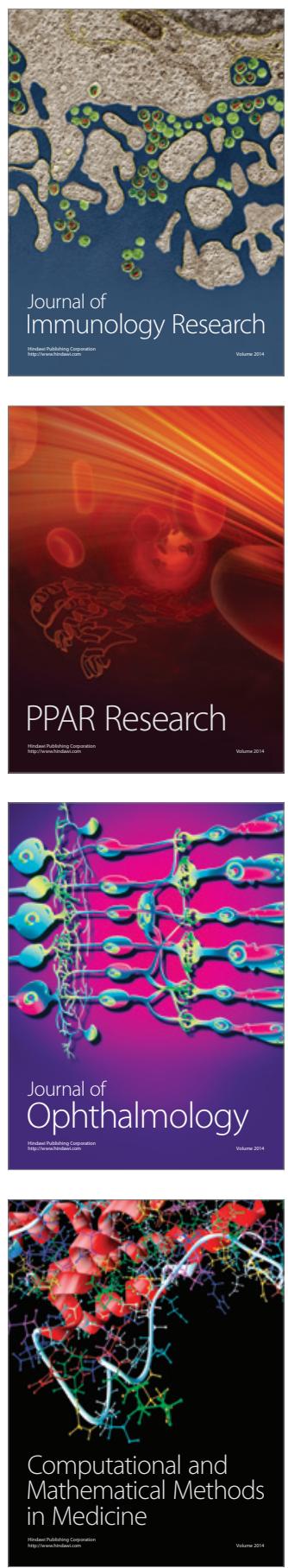

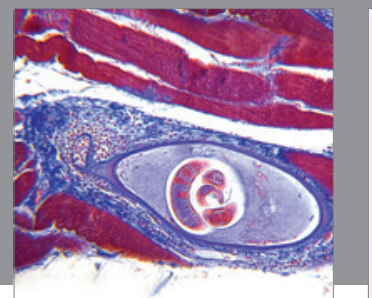

Gastroenterology

Research and Practice
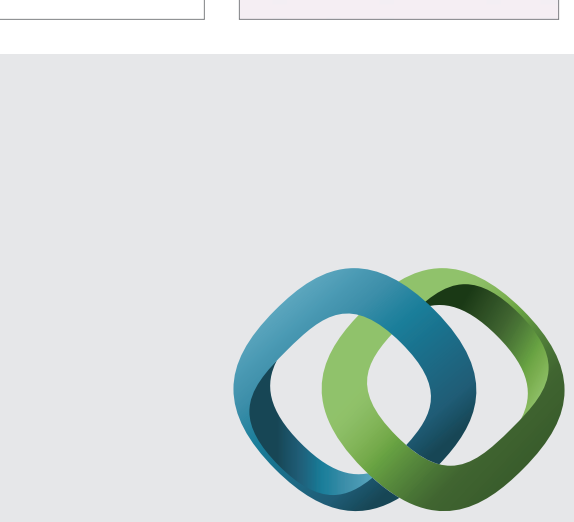

\section{Hindawi}

Submit your manuscripts at

http://www.hindawi.com
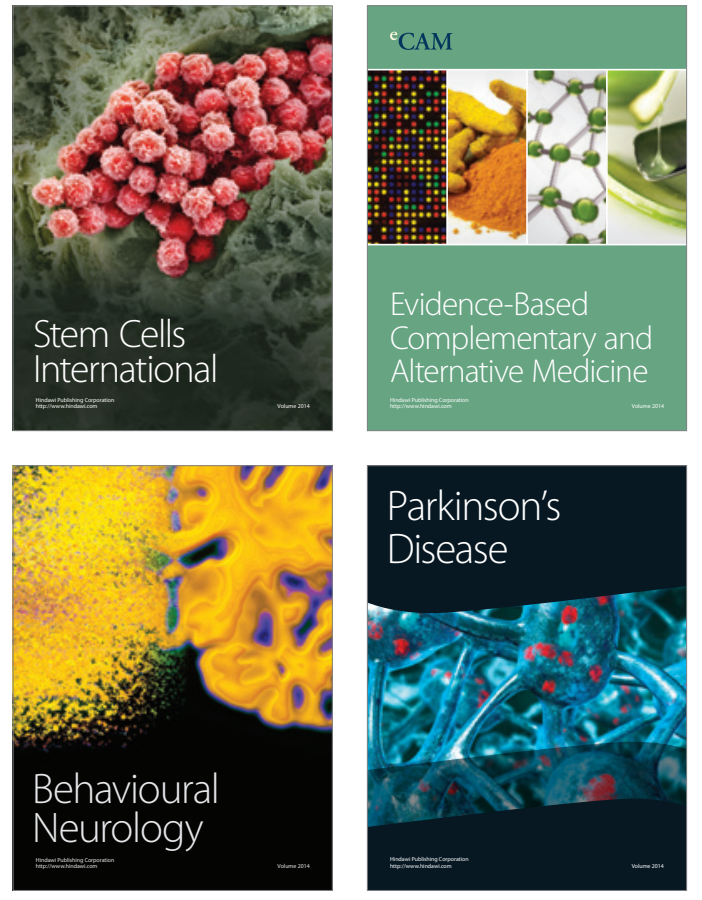
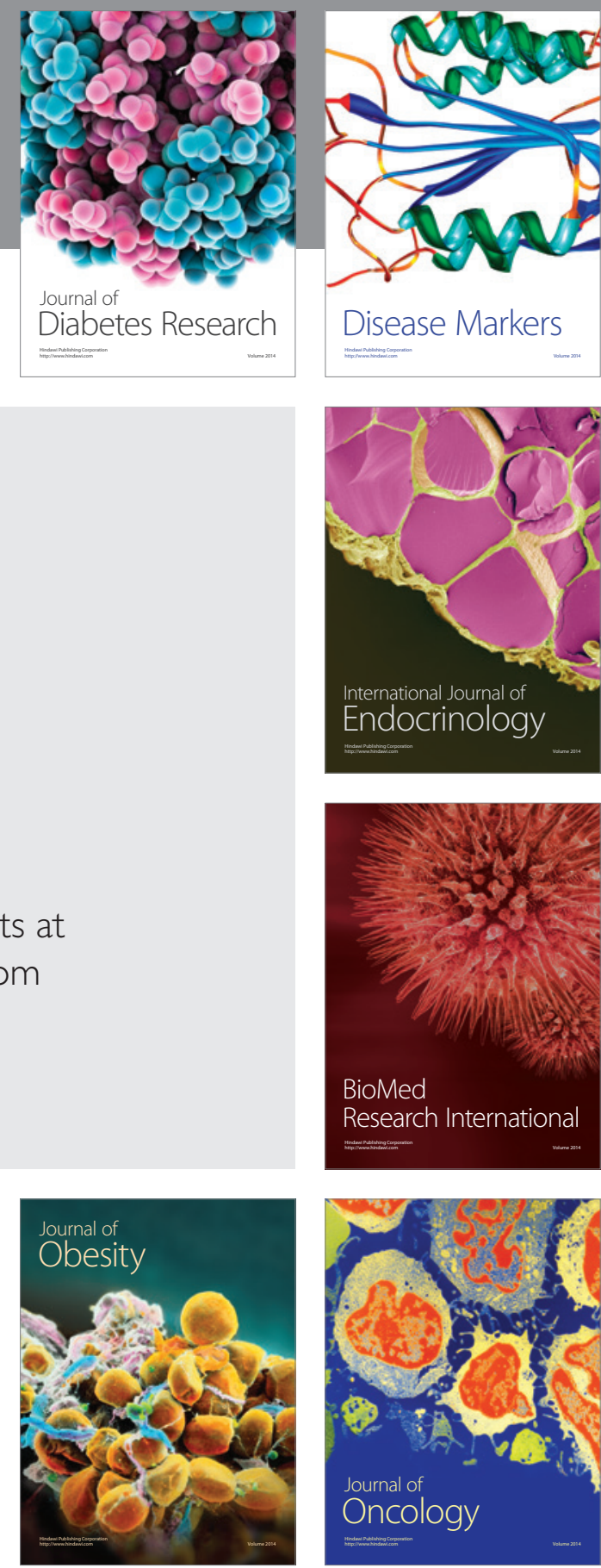

Disease Markers
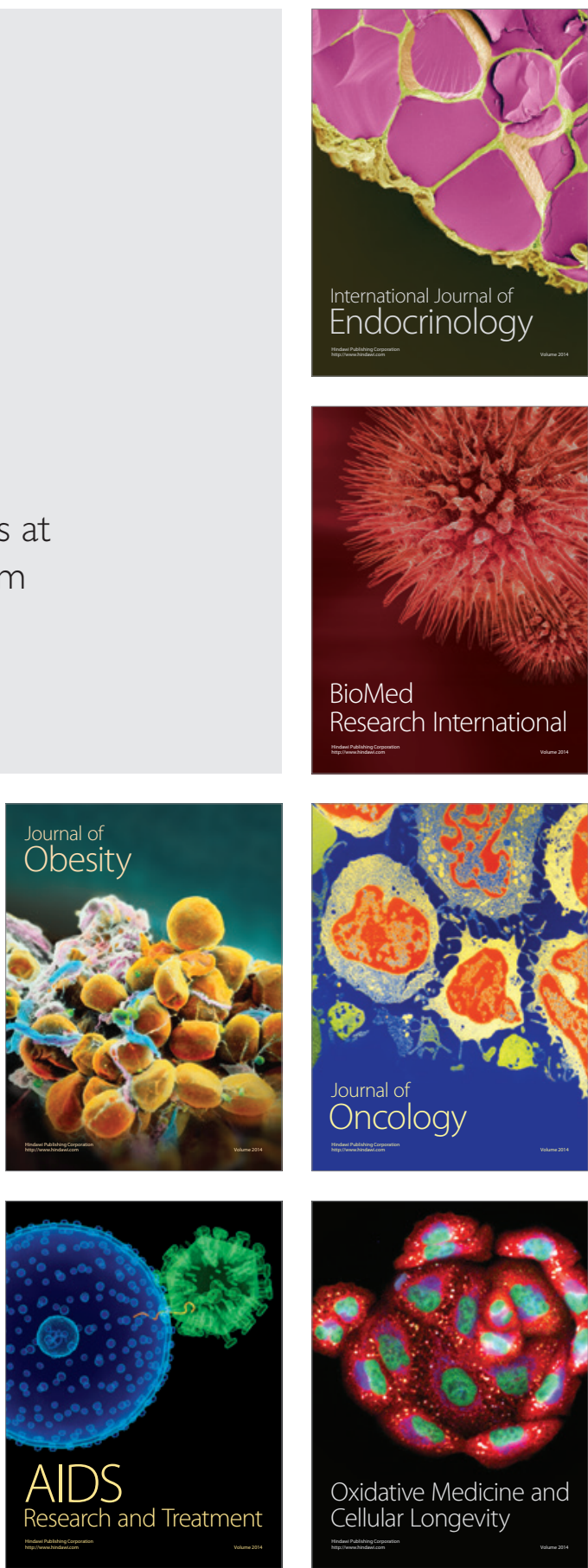